\title{
One-Dimensional Copper Coordination Polymer: Preparation and Structure of Bis(1,3,5-benzenetricarboxylato)(4,4-bipyridine)copper(II)
}

\author{
Hyun Sue Huh, Dongwon Min, Yeon Kyoung Lee, and Soon W. Lee* \\ Deparment of Chemistry and School of Molectlar Science (BK21), Sungknthican Lniversity, Suwon t40-746, Korea \\ Recerved December 12,2001
}

Keywords : One-dimensional. Copper coordination polymer. Benzenetricarboxylate. Bipyridine.

\begin{abstract}
Recently a variety of coordination polymers based on metalligand coordinative covalent bonding have received considerable attractions due to their novel topology and interesting functions. ${ }^{1.6}$ In particular. much attention has been paid to porous high-dimensional coordination polymers. because of their potential zeolite-like applications. ${ }^{7.15}$ For the preparation of this type of polymers. 1.3.5-benzenetricarboxylic acid $\left(\mathrm{btcH}_{3}\right)$ is widely employ'ed because of its potential role as a multidimensional ligand. ${ }^{11-13}$ For instance. Yaghi and co-workers reported the hydrothermal reaction between metal(II) acetate tetrahy'drate. [M(OAc) $: 4 \mathrm{H}_{2} \mathrm{O}: \mathrm{M}$ $=\mathrm{Co} . \mathrm{Ni}$. or $\mathrm{Zn}]$. and $\mathrm{btcH}_{3}$ to give 3-D coordination polymers of the type $\mathrm{M}_{3}(\mathrm{btc})_{2} \cdot 12 \mathrm{H}_{2} \mathrm{O} .^{13}$

During the past years. several two- and three-dimensional coordination polymers have been prepared from transitionmetal templates with mixed ligands of carboxylates and py ridyls. which can act as multidentate organic spacers. For example. a series of high-dimensional open frameworks were recently reported in which the combinations of such organic spacers as btc $\mathrm{H}_{3}$. 1.4-benzenedicarboxylic acid. py razine and 4.4'-bypidine (bpy) were utilized. ${ }^{14.16}$

We recently reported a one-dimensional copperpyridinedicarboxylate polymer that contains square-planar $\mathrm{Cu}(\mathrm{II})$ centers exhibiting antiferromagnetic coupling. ${ }^{17}$ We became interested in preparing high-dimensional coordination polymers with mixed ligands. In this context. we set out to prepare copper coordination polymers with btc $\mathrm{H}_{3}$ and bpy by hydrothennal reactions. Unexpectedly, the hydrothermal reaction of copper nitrate $\left[\mathrm{Cu}\left(\mathrm{NO}_{3}\right)_{2} \cdot 2.5 \mathrm{H}_{2} \mathrm{O}\right]$ with the mixed ligands of btc $\mathrm{H}_{3}$ and bpy gave a one-dimensional coordination polymer with an empirical formula of $\mathrm{Cu}\left(\mathrm{btch} \mathrm{H}_{2}\right)_{2}$ (bpy) (1). Herein, we report the preparation, structure. and thernal property of polymer 1 .
\end{abstract}

\section{Experimental Section}

$\mathrm{Cu}\left(\mathrm{NO}_{3}\right)_{2}=2.5 \mathrm{H}_{5} \mathrm{O}$. 1.3.5-benzenetricarboxylic acid $\left(\mathrm{btcH}_{3}\right)$, and $\mathcal{H}^{\prime}, \mathrm{f}^{\prime}$-bipyridine (bpy) were purchased and used without further purifications. IR spectra were recorded with a Nicolet 320 FT-IR spectrophotometer. Themogravimetric analyses were carried out on a TA4000/SDT 2960 instrument. Elemental analyses were performed by the Korea Basic Science

Corresponding author. Phone: +82-31-290-7066; Fax: +82-31290-7075; E-mail: swlee âchem.skinackr
Institute

Preparation of $\mathrm{Cu}(\mathrm{btcH})_{2}(\mathrm{bpy})$ (1). A mixture of $\mathrm{Cu}\left(\mathrm{NO}_{3}\right)_{2}=2.5 \mathrm{H}_{2} \mathrm{O}(0.111 \mathrm{~g} .0 .476 \mathrm{mmol}) . \mathrm{btcH}_{3}(0.100 \mathrm{~g}$. $0.476 \mathrm{mmol}$ ). bpy $(0.074 \mathrm{~g} .0 .476 \mathrm{mmol})$. and $\mathrm{H}_{2} \mathrm{O}(6 \mathrm{~mL})$ in the mole ratio of $1: 1: 1: 700$ was heated in a $23-\mathrm{mL}$ Teflon-lined-reaction vessel at $180^{\circ} \mathrm{C}$ for 3 days and then cooled to room temperature by air-cooling. The blue product was collected by filtration. washed with $\mathrm{H}_{2} \mathrm{O}(2 \times 5 \mathrm{~mL})$ and ethanol $(2 \times 5 \mathrm{~mL})$, and then air-dried to give $\mathrm{Cu}\left(\mathrm{btcH} \mathrm{H}_{2}\right)_{2}-$ (bpy) $(0.072 \mathrm{~g} .0 .129 \mathrm{mmol}, 27.1 \%$ yield). Anal. Calcd for $\mathrm{C}_{28} \mathrm{H}_{1} \mathrm{~N}_{2} \mathrm{O}_{12} \mathrm{Cu}\left(M_{\mathrm{r}}=637.98\right):$ C. $52.71:$ N. 4.39: H. 2.84. Found: C. 51.80: N. 4.07: H. 2.80. IR ( $\left.\mathrm{KBr}, \mathrm{cm}^{-1}\right)$ : 1699. 1613, 1552, 1430, 1395, 1289, 1169, 1116,823, 672 .

Table 1. X-ray datá collection and structure refinement

\begin{tabular}{|c|c|}
\hline formula & $\mathrm{C}_{23} \mathrm{H}_{18} \mathrm{~N}_{2} \mathrm{O}_{12} \mathrm{Cu}$ \\
\hline fiw & 637.98 \\
\hline temperature, $\mathrm{K}$ & $295(2)$ \\
\hline crystal system & monoclinic \\
\hline space group & $\mathrm{C} 2 / \mathrm{c}$ \\
\hline$a, \AA$ & $10.717(2)$ \\
\hline$b, \AA$ & $11.089(3)$ \\
\hline$c \dot{A}$ & $22.778(5)$ \\
\hline$\beta, \operatorname{deg}$ & $101.39(1)$ \\
\hline$I: A^{3}$ & $2654(1)$ \\
\hline Z & 4 \\
\hline$d_{c \alpha l}, \mathrm{~g} \mathrm{cml}^{-3}$ & 1.597 \\
\hline$\mu, \mathrm{mm}^{-1}$ & 0.896 \\
\hline$T_{\text {tேแ }}$ & 0.7197 \\
\hline$T_{\operatorname{taxx}}$ & 0.9207 \\
\hline$F(000)$ & 1300 \\
\hline $2 \theta$ range $\left({ }^{\circ}\right)$ & $3.5-50$ \\
\hline scanl type & $\omega$ \\
\hline scan speed & variable \\
\hline No. of reflns measured & 2439 \\
\hline No. of reflns unique & 2309 \\
\hline No. of retlns with $I>2$ G $I$ ) & 2019 \\
\hline No. of params refined & 234 \\
\hline Max., in $\Delta \rho\left(\mathrm{e} \AA^{-3}\right)$ & 0.419 \\
\hline $\mathrm{Minl}$, in $\Delta \rho\left(\mathrm{e} A^{-3}\right)$ & -0.407 \\
\hline$G O F$ on $F^{2}$ & 1.039 \\
\hline$R$ & 0.0325 \\
\hline$w R_{1}^{a}$ & 0.0819 \\
\hline
\end{tabular}

${ }^{a_{1} R_{2}}=\Sigma\left[1+\left(F_{o}^{2}-F_{i}^{2}\right)^{2}\right] \sum\left[1\left(F_{o}^{2}\right)^{2}\right]^{1 / 2}$ 
Table 2. Atonic coordinates $\left(\times 10^{4}\right)$ and equivalent isotropic displacement parameters $\left(A^{3} \times 10^{3}\right)$

\begin{tabular}{|c|c|c|c|c|}
\hline & $x$ & $y$ & $z$ & $U(\mathrm{eq})^{\prime \prime}$ \\
\hline $\operatorname{Cu}(1)$ & 5000 & $3523(1)$ & 7500 & $19(1)$ \\
\hline$O(1)$ & $3929(1)$ & $3538(1)$ & $8144(1)$ & $23(1)$ \\
\hline$O(2)$ & $5968(1)$ & $3437(2)$ & $8569(1)$ & $28(1)$ \\
\hline$O(3)$ & $891(2)$ & $4806(2)$ & $9460(1)$ & $53(1)$ \\
\hline$O(4)$ & $1418(2)$ & $4+24(2)$ & $10445(1)$ & $44(1)$ \\
\hline$O(5)$ & $6927(2)$ & $2253(3)$ & $10685(1)$ & $58(1)$ \\
\hline$O(6)$ & $6014(2)$ & $3263(3)$ & $11336(1)$ & $62(1)$ \\
\hline$N(1)$ & 5000 & $1728(2)$ & 7500 & $21(1)$ \\
\hline$N(2)$ & 5000 & $5322(2)$ & 7500 & $23(1)$ \\
\hline$C^{\prime}(1)$ & $4448(2)$ & $3542(2)$ & $9216(1)$ & $22(1)$ \\
\hline$C(2)$ & $3245(2)$ & $3945(2)$ & $9283(1)$ & $26(1)$ \\
\hline$C(3)$ & $2954(2)$ & $4022(2)$ & $9853(1)$ & $26(1)$ \\
\hline$C(4)$ & $3858(2)$ & $3704(2)$ & $10358(1)$ & $27(1)$ \\
\hline$C(5)$ & $5048(2)$ & $3282(2)$ & $10292(1)$ & $26(1)$ \\
\hline$C^{\prime}(6)$ & $5335(2)$ & $3202(2)$ & $9722(1)$ & $26(1)$ \\
\hline$C(7)$ & $4812(2)$ & $3498(2)$ & $8609(1)$ & $21(1)$ \\
\hline$C^{\prime}(8)$ & $1666(2)$ & $4+57(2)$ & $9919(1)$ & $30(1)$ \\
\hline$C(9)$ & $6031(2)$ & $2944(3)$ & $10834(1)$ & $33(1)$ \\
\hline$C(10)$ & $3917(2)$ & $1104(2)$ & $7315(1)$ & $27(1)$ \\
\hline$C(11)$ & $3877(2)$ & $-147(2)$ & $7 \hat{3} 15(1)$ & $28(1)$ \\
\hline$C(12)$ & 5000 & $-800(3)$ & 7500 & $22(1)$ \\
\hline$C(13)$ & 5000 & $-2152(3)$ & 7500 & $22(1)$ \\
\hline$C(14)$ & $3989(2)$ & $-2806(2)$ & $7167(1)$ & $27(1)$ \\
\hline$C(15)$ & $5970(2)$ & $5944(2)$ & $7823(1)$ & $27(1)$ \\
\hline
\end{tabular}

"Equivalent isotropic $U$ defined as one-third of the trace of the orthogonalized $U_{j}$ tensor.

$\mathrm{X}$-ray Structure Determination. All X-ray data were collected with the use of a Siemens $\mathrm{P} 4$ diffractometer equipped with a Mo X-ray tube and a graphite-crystal monochromator. The orientation matrix and unit-cell parameters were determined by least-squares analyses of the setting angles of 21 reflections in the range of $10.0^{\circ}<2 \theta<25.0^{\circ}$. Three checkreflections were measured every 100 reflections throughout data collection and showed no noticeable variations in intensity. Intensity data were corrected for Lorenz and polarization effects. Decay corrections were also made. The intensity data were empirically corrected for absorption with $\psi$ scan data. All calculations were carried out with the use of the SHELXTL progranss. ${ }^{18}$

A blue crystal of 1 , shaped as a rod of approximate dimensions of $0.60 \times 0.26 \times 0.20 \mathrm{~nm}^{3}$. was used for crystaland intensity-data collection. The unit-cell parameters and systematic absences. $h k l(h+k=2 n+1)$ and $h 0 l(l=2 n+1)$, indicated two possible space groups: $C c$ (non-centrosymmetric) and $(2 / c$ (centrosymmetric). A statistical analy sis of reflection intensities suggested a centrosynmetric space group. and the structure analysis converged only in $\mathrm{C} 2 / \mathrm{c}$. The structure was solved by direct methods. All non-hydrogen atoms were refined anisotropically. All hydrogen atoms were located in the difference Fourier maps. Details on crystal data and intensity data are given in Table l. Final atomic coordinates are shown in Table 2. Selected bond distances and bond angles are given in Table 3 .

\section{Results and Discussion}

Preparation. A one-dimensional $\mathrm{Cu}$ (II) coordination polymer with an infunite network was prepared from a mixture of $\mathrm{Cu}\left(\mathrm{NO}_{3}\right)_{2}, 2.5 \mathrm{H}_{2} \mathrm{O}$, btc $\mathrm{H}_{3}$, bpy, and $\mathrm{H}_{2} \mathrm{O}$ in the mole ratio of $1: 1: 1: 700$ by heating it at $180^{\circ} \mathrm{C}$ for 3 days (eq 1). Although we do not know the driving force for this reaction, the coordinative covalent bonding and the octahedral preference of the copper metal center seem to play a role.

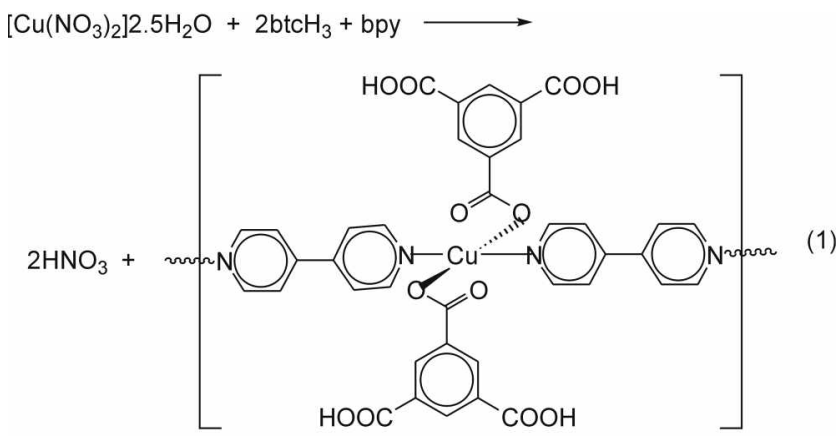

The compound 1 is air-stable and is not soluble in common organic solvents. Its IR spectrum shows the asymmetric and symmetric carboxylate stretches for $\mathrm{btcH}_{2}{ }_{2}^{-1}(1699$, 1430. 1395 , and $1289 \mathrm{~cm}^{-1}$ ). The disappearance of the carbonyl band $\left(172 \mathrm{I} \mathrm{cm}^{-1}\right)$ in btcH $\mathrm{b}_{3}$ and some characteristic bands $\left(1590\right.$ and $\left.1532 \mathrm{~cm}^{-1}\right)$ in the free bpy suggests that both btc $\mathrm{H}_{3}$ and bpy might have been coordinated to copper metals during the reaction. The formulation of 1 has been further confirmed by X-ray diffraction and elemental analysis.

Thermogravimetric analysis (TGA) shows that title polymer is stable up to $280^{\circ} \mathrm{C}$ without decomposition (Figure l). A drastic weight loss is observed from 330 to $360^{\circ} \mathrm{C}$, which corresponds to the loss of one $\mathrm{btcH}_{2}{ }^{-}$ligand and one bpy

Table 3. Selected bond distances $(\AA)$ and bond angles (")

\begin{tabular}{|c|c|c|c|c|c|}
\hline $\mathrm{Cul-NI}$ & $1.990(3)$ & $\mathrm{Cu} 1-\mathrm{N} 2$ & $1.995(3)$ & Cul-Ol\#l & $2.034(2)$ \\
\hline $\mathrm{Cul}-\mathrm{Ol}$ & $2.034(2)$ & & & & \\
\hline $\mathrm{N} 1-\mathrm{Cu} 1-\mathrm{N} 2$ & $180.00(1)$ & $\mathrm{NI}-\mathrm{Cul}-\mathrm{Ol} \# \mathrm{l}$ & $90.45(4)$ & N2-Cul-OI\#I & $89.55(5)$ \\
\hline $\mathrm{N} 1-\mathrm{Cul}-\mathrm{Ol}$ & $90.45(5)$ & $\mathrm{N} 2-\mathrm{Cul}-\mathrm{O} 1$ & $89.55(4)$ & $\mathrm{Ol} \# \mathrm{I}-\mathrm{Cul}-\mathrm{Ol}$ & $179.09(9)$ \\
\hline $\mathrm{O} 2-\mathrm{C} 7-\mathrm{Ol}$ & $121.5(2)$ & $\mathrm{O} 3-\mathrm{C} 8-\mathrm{O} 4$ & $124.2(2)$ & O6-C9-O5 & $124.3(2)$ \\
\hline
\end{tabular}

Svmmetry transfomations used to generate equivalent atoms: $1=-x-1, y-z+32$ : $2=-x-1, y-1,-z-32$. 


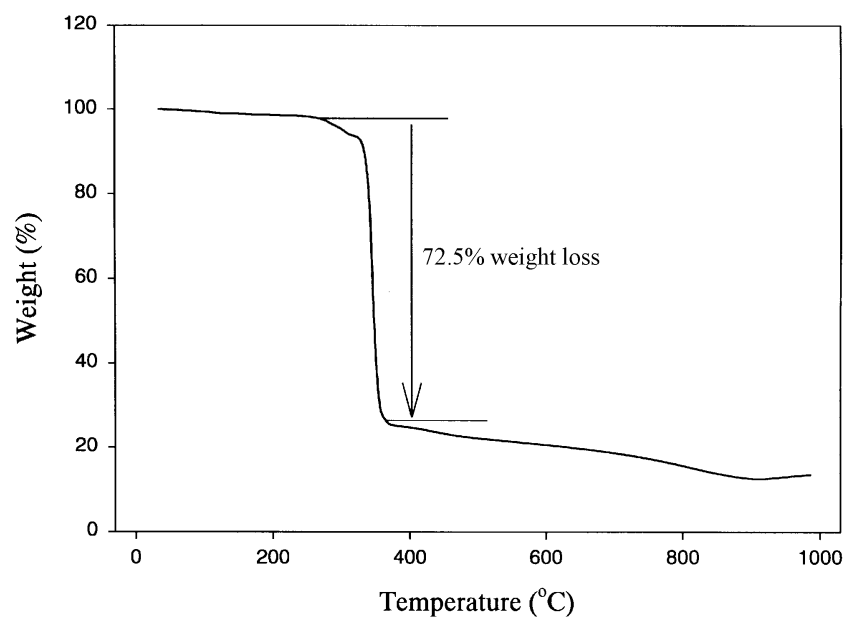

Figure I. Thermogravintetic analysis results for $\mathbf{I}$.

ligand. Above $505^{\circ} \mathrm{C}$, the second process occurs to give a solid residue $(22.1 \%)$.

Structure. Figure 2 shows the local coordination of the copper center. The Cul, N1, N2, C12, and C13 atoms lie on the crystallographic 2 -fold rotation $\left(C_{2}\right)$ axis, and this explains why this crystal has the $Z$ value of 4 instead of 8 . The coordination sphere of copper can be described as square planar, with two oxygen atoms from two btcH $\mathrm{H}_{2}^{-}$ligands and two nitrogen atoms from two bpy ligands. The formal oxidation state of the copper metal is +2 . The $\mathrm{C}-\mathrm{O}$ bond distance in the coordinated and uncoordinated carboxylates are equal within experimental error.

The equatorial plane, defined by $\mathrm{Cu}, \mathrm{N} 1, \mathrm{~N} 2, \mathrm{O} 1$, and Ol\#1 (\#1 $=-x+1, y,-z+3 / 2)$, is perfectly planar due to its generation by symmetry operation. Two pyridine moieties in the bpy ligand are twisted from each other by $18.1(1)^{\circ}$, and have the dihedral angles of $65.61(7)^{\circ}$ and $83.76(7)^{\circ}$ with respect to the equatorial plane. The benzene ring in the $\mathrm{btcH}_{2}^{-}$ligand is essentially planar with the average atomic displacement of $0.0062 \AA$ and has the dihedral angle of $72.66(6)^{\circ}$ with respect to the equatorial plane. Two of the three carboxylate groups are considerably twisted from the benzene ring with the dihedral angles of $17.2(1)^{\circ}$ and 19.6 (3)', and the remaining one $(03,04$, and $\mathrm{C} 8$ ) is relatively coplanar with the dihedral angle of $4.6(3)^{\prime}$. The bpy acts as a bridging ligand between two $\mathrm{Cu}$ metals. Interestingly, the $\mathrm{btcH}_{2}$ ligand acts as a monodentate oxygen-donor ligand and does not link the $\mathrm{Cu}$ metals. In other words, only one (O1) out of the six carboxylate oxygens in the $\mathrm{btcH}_{2}^{-}$ligand is coordinated to the copper metal.

The unit-cell diagram along the $a$-axis demonstrates a onedimensional polymeric structure of $\mathbf{1}$, as shown in Figure 3. Fach one-dimensional array is formed by the bridging bpy ligands connecting $\mathrm{Cu}$ metals in the $b$-axis direction. These 1-D arrays stack on top of each other along the $c$-axis with a separation of one-half of the $c$-axis length (11.4 $\AA$ ). The hydrogen atoms in the carboxylate groups, which are not coordinated to the copper metal, are involved in intermolecular hydrogen bonds; $\mathrm{O} 4-\mathrm{HO} 4=0.655 \AA, 04 \cdots \mathrm{O} 3=2.667$ $\AA . \mathrm{HO} 4 \cdots \mathrm{O} 3=2.014 \AA$, and $\mathrm{O} 4-\mathrm{HO} 4 \cdots \mathrm{O} 3=175.40^{\circ} ; \mathrm{O} 5-$ $\mathrm{HO}=0.747 \AA, 05 \cdots \mathrm{O} 2=2.655 \AA, \mathrm{HO} 5 \mathrm{OO} 2=1.935 \AA$. and $05-\mathrm{HO} 5 \mathrm{O} 2=161.69^{\circ}$. These hydrogen bonds are associated with the center of symmetry and C-centering. Williams and co-workers very recently reported that the solvothermal or hydrothermal reaction of copper(II) nitrate. terephthalic acid, and bpy in the mole ratio of $1: 1: 1$ gives a 3-D copper polymer [Cu, $\left\{\left(1,4-\mathrm{C}_{6} \mathrm{H}_{4} \mathrm{COO}\right)_{2}\right\}$ (bpy) $)_{2}$, which has a $\mathrm{Cu}(\mathrm{I})-\mathrm{Cu}(\mathrm{II})$ dimeric unit. ${ }^{\mathrm{l}}$ On the other hand, we employed copper(Il) nitrate, $\mathrm{btcH}_{\hat{i},}$ and bpy and obtained a 1-D copper coordination polymer.

Several attempts to enhance the dimensionality of a lowdimensional coordination polymer have recently appeared in the literature. For example, l.i and co-workers reported the effect of $\mathrm{pH}$ on the dimensionality of coordination polymers. ${ }^{1 / 3}$ In addition, 7aworotko and Moulton proposed the manipulation of $2 \mathrm{D}$ polymers to be a plausible entry into the generation of $3 \mathrm{D}$ polymers. Their proposed strategies are the cross-linking of 2D structures with spacer ligands and the interpenetration of identical or different $2 \mathrm{D}$ networks. ${ }^{20.21}$ Furthermore, Keller and co-workers showed the dimensional control of $\mathrm{Cu}(1)$-bis(4-pyridyl)ethylene coordination network by varying the solvent composition. ${ }^{22}$ In this context, we have tried to enhance the dimensionality of polyıner 1 by varying the reaction conditions such as reaction time ( $1-3$ days), $\mathrm{pH}(3-11)$, mole ratio $(1: 1-3: 1)$, and solvent

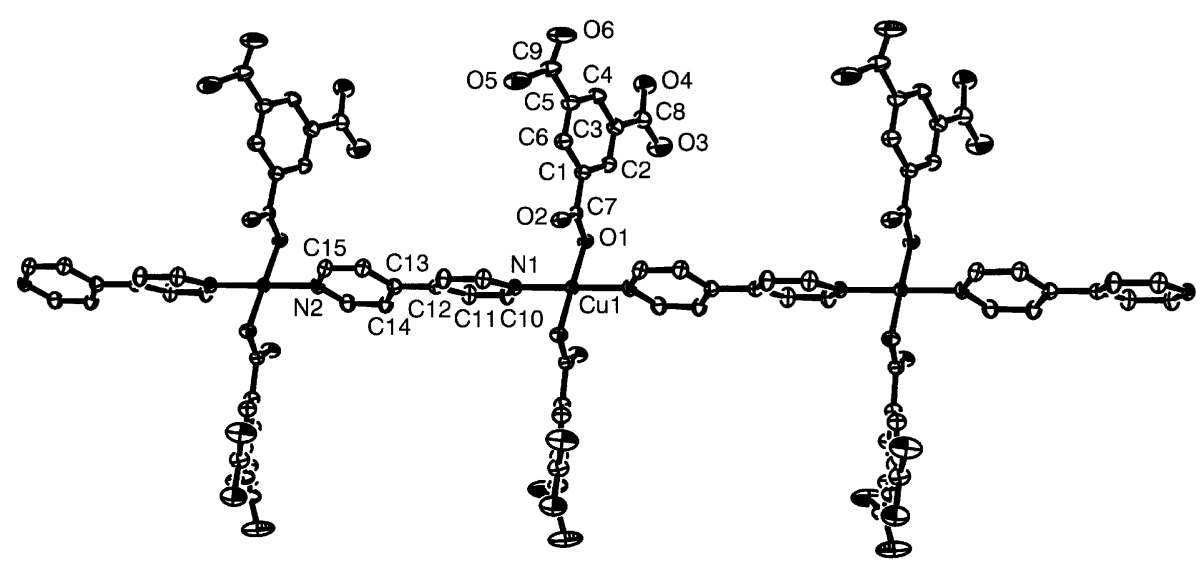

Figure 2. ORITP draw ing of 1 showing the atom-labeling scheme and $50 \%$ probability thermal eflipsoids. 


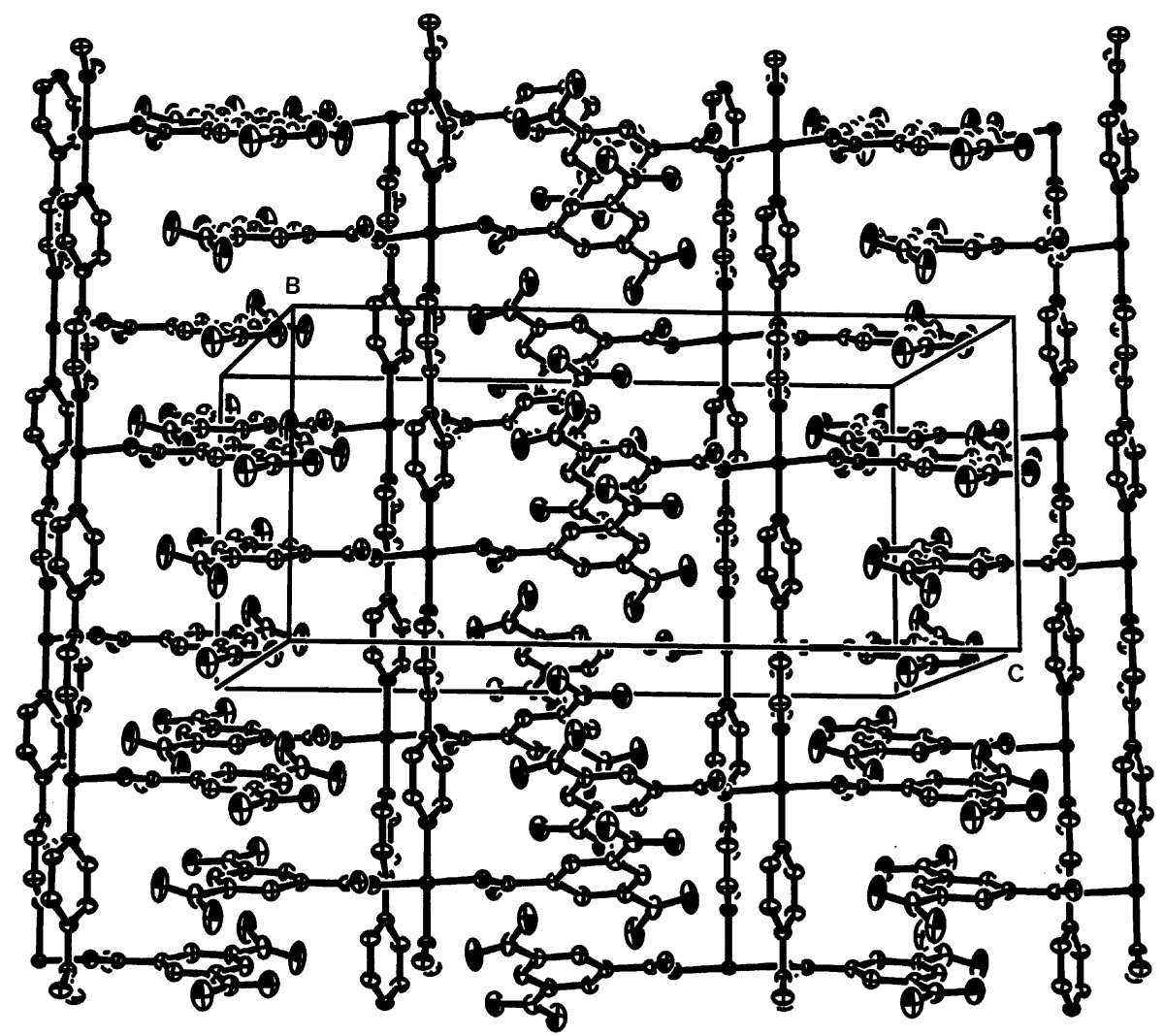

Figure 3. A packing diagram along the a-axis.

composition $\left(\mathrm{H}_{2} \mathrm{O} ; \mathrm{ROH}=4 ; 1 ; \mathrm{R}=\mathrm{Me}\right.$, F.t, or $n$-Bu), Variations in the reaction time or mole ratio gave the same product, which was confirmed by IR and unit-cell parameters. On the other hand, variations in the $\mathrm{pH}$ and solvent composition brought about the decomposition of products. In addition, instead of the bpy ligand, we tried to employ some other dipyridyl ligands (pyrazine, trans-1,2-bis(4pyridyl)ethylene, trans-1,2-bis(4-pyridyl)ethane. and 4,4'trimethylenedipyridine). However, these ligands gave only poorly crystalline or powder products.

In sumınary, we have structurally characterized $\mathrm{Cu}(\mathrm{btcH})_{2}-$ (bpy) (1), which was prepared by the hydrothermal reaction of $\mathrm{Cu}\left(\mathrm{NO}_{3}\right)_{2} \cdot 2.5 \mathrm{H}_{2} \mathrm{O}$ with the mixed ligands of $1,3,5-$ benzenetricarboxylic acid $\left(\mathrm{btcH}_{i}\right)$ and 4,4'-bipyridine (bpy). This polymer has a one-dimensional network and exhibits thermal stability up to $280^{\circ} \mathrm{C}$

Acknowledgment. This work is based on research sponsored by the Korea Ministry of Education under grant BSRI-98-3420.

Supplementary Material. [ables of full bond distances and bond angles, anisotropic thermal parameters, and atomic coordinates of hydrogen atoms are available from the author Soon W. Lee.

\section{References}

I. Desiraju. (1. R. Constal Enginering: The Design of Organic Solids: IIsevier: New York. 1989: Vol. 54.

2. Batlen. S. R.: Robson. R. Angew. (hem., Int. Ld lingt. 1998. 37. 1461.

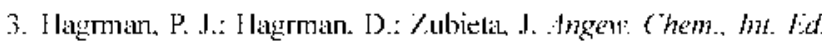
1999. 38.2638.

4. Yaghi. O. M.: Li. H.: Davis. C.: Richardson. D.: Groy. I. L. Acc Chem. Res. 1998. 3/. 474.

5. Fvans, O. R.: lin. W horg. (hem 2000 39, 2189

6. Fvans. O. R.: lin. W. Corstal Grow th \& Design 2001. 1.8.

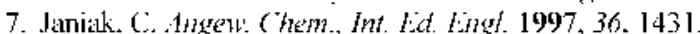

8. Munakala. M.: Wu. L. P': Kuroda-Sowa. I. Adv lhorg. Chem. 1999. 46.173 .

9. Chuj. S. S.-Y.: Lo. S. M.-F.: Charmant. J. P. H.: Orpen. A. G.: Williams. I. D. Soience 1999, 283,1148

10. Kiang, Y.-II,: Gardner, (i, B.: l.ec. S.: X11, 7.: I obkovsky, Г, B., J Am. (hem. Soc. 1999. /2/. 8204

11. Kinn. J. I1.: Chen. 13.: Reineke. T. M.: L.j. IL.: I:ddaoudi. M.: Woler. D. B.: OKeetle. M.: Yaghi. O. M. J. Am. Chem. So 2001. $/ 23.8239$

12. Eddaoudi. M.: Li. H.: Yaghí. O. M. J. Am. Chem. Soc. 2000. /22. 1391.

13. Yaghi, O, M.: 1.i, II.: Groy, T. I. J. Am. Chem Soc 1996. H8. 9096.

14. I.o. S. M.-1:. Chui. S. S.-Y.: Shek. L. Y.: I.in. Z.: Zhane. X. X.: Wen. G. H.: Willians. L. D. J. Am. Chem. Soc. 2000. /22.6293.

15. Shi. Z.: Zhang. L.: Gao. S.: Yang. G.: Hua. 1.: Gao. L.: Feng. S. horg. Chem. 2000. 39. 1990.

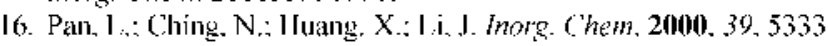

17. Min. D.: Yoon. S. S.: Jung. I).-Y.: L.ee. C. Y.: Kim. Y.: I Ian. W. S.: I.e. S. W. Irorg. (him .1cta 2001. 32t. 293.

18. Bruker. SHELXIL. Sinztctre Determination Softuare Programs: Bruker Analstical X-ray Instruments lnc.: Madison. Wisconsin. USA. 1997.

19. Pan, 1.: Thomas, $\Gamma$ : Michelle. B, S. Hluang. $X_{\text {: }}$ [., I. horg. (hem. 2001. 40.1271.

20. Zaworotko. M. J.: Moulton. B. (hem. Rev 2001. IH. 283.

21. Laworotko. M. J. Chem. Conmmn. (leature article) 200I. l.

22. Knaust. J. M.: Lopez. S.: Keller. S. W. Inorg. Chim. Acta 2001. 32. 81. 